\title{
Analysis of SEWB Activities on Appropriate Technology in Korea and in Developing Countries Including Cambodia
}

\author{
Sujung Lee ${ }^{1,2}$, Yoonjung $\mathrm{Choi}^{3}$, Sanghee Park ${ }^{3}$, Yongsoo Kim ${ }^{3,4}$, Seongpil Jeong ${ }^{1,5, \uparrow}$ \\ ${ }^{1}$ Water Cycle Research Center, Korea Institute of Science and Technology, \\ 5, Hwarang-ro 14gil, Seongbuk-gu, Seoul 02792, Republic of Korea \\ ${ }^{2}$ Department of Environmental Engineering, Seoul National University of Science and Technology, \\ 232 Gongneung-ro, Nowon-gu, Seoul 01811, Republic of Korea \\ ${ }^{3}$ Scientists and engineers without borders (Room 313, Hanyang Institute of Technology (HIT)), \\ Hanyang University, 222 Wangsimni-ro, Seongdong-gu, Seoul 04763, Republic of Korea \\ ${ }^{4}$ Department of Nuclear Engineering, Hanyang University, 222 Wangsimni-ro, Seongdong-gu, Seoul 04763, Republic of Korea \\ ${ }^{5}$ Division of Energy \& Environment Technology, KIST school, Korea University of Science and Technology, \\ 5, Hwarang-ro 14gil, Seongbuk-gu, Seoul 02792, Republic of Korea
}

\section{한국 및 개도국(캄보디아 등) 사례로 본 국경없는 과학기술자회의 적정기술 분야 사업 분석}

\author{
이수정 ${ }^{1,2}$, 최윤정 ${ }^{3}$ 박상희 ${ }^{3}$, 김용수 ${ }^{3,4}$, 정성필 $1,5, \uparrow$ \\ 1한국과학기술연구원 물자원순환연구센터, 02792 서울특별시 성북구 화랑로 14 길 5 \\ ${ }^{2}$ 서울과학기술대학교 환경공학과, 04763 서울특별시 노원구 공릉로 232 \\ ${ }^{3}$ (사)국경없는과학기술자회, 04763 서울특별시 성동구 왕십리로 222 (한양대학교 한양종합기술연구원(HIT) 313 호) \\ ${ }^{4}$ 한양대학교 원자력공학과, 04763 서울특별시 성동구 왕십리로 222 \\ ${ }^{5}$ 과학기술연합대학원대학교 KIST 스쿨 에너지-환경 융합공학과, 02792 서울특별시 성북구 화랑로 14 길 5
}

\begin{abstract}
사회로부터 고립된 마을에 거주하여 열악한 위생 환경에 놓여 있는 개도국 소외계층에게 과학과 기술을 지원하는 전 문가 단체로서 2009년 국내 국경없는과학기술자회(SEWB)가 설립되었다. UN의 17개 SDG (Sustainable development goals)에 따라 전 세계적으로 개도국 소외계층의 삶의 질을 개선하기 위한 사업들이 추진되고 있다. SDG가 추진된 2016년 이후 개도국과 선진국의 사회적 인프라 격차를 줄이고, 적정기술 보급을 통한 개도국의 지속 가능한 발전을 도 모하는 방향으로 $\mathrm{SEWB}$ 의 국내 및 해외 사업이 수행되어 왔다. 국내 전문가 및 학생들을 대상으로 적정기술 분야 국 제 학회(International conference on appropriate technology, ICAT)와 강의, 경진대회를 개최하였다. 캄보디아를 포함한 6개 개도국을 대상으로 (재)자연드림씨앗재단 식수 공공성 사업과 적정기술 해외 봉사활동을 수행해왔다. 특히, 2019 년부터는 '캄보디아 고립 마을 주민의 삶의 질 개선과 소득 증대를 위한 적정기술 마을 조성 사업’을 수행하면서 캄보 디아 봇뱅 마을에서 물, 전기, 인프라, 농업 분야의 사회적 인프라 구축하고 있다. SEWB의 적정기술 분야 사업은 한 정된 자원으로, 개도국에 적정기술 기반의 장치를 보급하고 개도국 국민의 복지와 생활수준 향상을 위한 통합 솔루션 을 제공할 수 있다. 향후 개도국 소외계층의 식수 부족 문제와 기아문제를 해소하는데 SEWB가 지속적으로 기여할 수 있을 것으로 판단된다.
\end{abstract}

Scientists and engineers without borders (SEWB) was established on 2009 as the NGO having specialist groups to support the underprivileged in developing countries living in the isolated area and having water and sanitation problems. After the SDGs were suggested by the UN on 2016, activities are globally conducted by the nation, NGO and etc. to improve health

${ }^{\dagger}$ To whom correspondence should be addressed.

E-mail: spjeong@kist.re.kr

Received: 2 April 2021, Revised : 12 May 2021, Accepted: 21 May 2021 and education of the underprivileged in developing countries. SEWB also have been conducted the projects in Korea and developing countries to reduce the gap of the infrastructure between the developed and developing countries and to help sustainable develop- 
ment in the developing countries by providing appropriate technology. In Korea, SEWB have been held international conference on appropriate technology (ICAT), lectures, and competitions for specialists and students. In developing countries including Cambodia and other 5 countries, SEWB have been provided water packages funded by iCOOP KOREA and volunteer opportunities. Since 2019, 'SEWB sustainable village development project' have been conducted in Bot Veng village, Cambodia to improve infrastructures on water, electricity, transportation, and agriculture by using desalination system, Solar Cow system, strengthened wooden bridge, and poultry farm, respectively. The developed solution for developing countries from SEWB could contribute to eliminate the water shortage and poverty.

KEYWORDS: Appropriate technology, Cambodia, SEWB, ICAT, Water package

서론

전 세계적으로 하루 소득 $\$ 1.9$ 이하의 극빈층은 약 6.89 억 명으로 심각한 가난 문제를 겪고 있다(The World Bank, 2020). 가난과 소득 불평등의 문제를 해결하기 위하여 UN 등 국제 기구가 국제개발 협력을 추진하여 왔다. UN은 국 제개발협력을 위하여 MDGs (Millennium development goals) 를 2000년에 제정하였으며 이 목표는 2015년까지 유지되었 다. 이 체제 하에서는 극빈층 또는 기아를 없애고, 초등 교 육을 보장하는 등의 최소한의 삶의 질을 확보하는데 그 목 적이 있었다. 2016년부터 2030년까지 UN은 SDGs (Sustainable development goals)라는 새로운 목표를 제안하였으며, 이 체 제 하에서는 전 세계 모든 국가들이 포용적인 제도나 사회 를 구축하고 환경의 지속 가능성을 확보하는 데 그 목적이 있다.

이러한 UN 체제의 변화에 따라서 전 세계적으로 개도국 을 지원하는 각종 사업의 형태도 변화해 왔다. 전 세계적으 로 선진국의 지원이 이루어져 왔으나 개도국의 국민들과 선진국 국민들의 삶의 수준 또는 질에는 여전히 격차가 있 다. 하루 평균 소득이 $\$ 1.9$ 이하인 극빈층의 비율이 $3 \%$ 이 상인 국가들은 주로 아프리카, 남아프리카 및 동남아시아 지역에 주로 분포하고 있었다(The world bank, 2020). UNFCCC의 TNA(Technology needs assessments) 우선 순위 결과에 따르면, 농업 $(87 \%)$, 물 $(79 \%)$, 인프라/주거(33\%), 기 후 관측 $(8 \%)$, 건강 $(8 \%)$ 등 다양한 기술 수요가 있는 것으 로 보고되었다(UNFCCC, 2021).

따라서, 이와 같은 불평등 또는 격차의 문제를 해결하기 위하여 국가규모의 $\mathrm{OECD}$ 에서 제공하는 $\mathrm{ODA}$ 사업의 형태 나, $\mathrm{NGO}$ 또는 종교, 개인 활동가 등에 의한 협력 등이 이 루어진 바 있다. 예를 들어, 국경없는 의사회의 경우 1971 년부터 전 세계를 대상으로 의료 목적의 구호 활동 등을 수 행해 오고 있으며, 이태석 신부님의 경우 아프리카 남부 지 역에서 병원 설립 및 수도 보급 사업 등을 수행한 바 있다.
과학기술분야에서도 안전한 먹는 물을 확보하고 위생 문 제를 해결할 수 있는 Engineers Without Borders (EWB)와 같은 단체가 호주(EWB Australia, 2021), 영국(EWB UK, 2021), 미국(EWB USA, 2021), 캐나다(EWB Canada, 2021) 등의 국가에 만들어졌다.

국내에서는 (사)국경없는과학기술자회(Scientists and Engineers Without Borders, SEWB, 2021)가 소외된 사람들의 빈 곤 해소 및 삶의 질 개선을 위하여 과학과 기술을 교육하 고 보급하는 전문가 단체로서 2009년 창립되었다. 창립 해 인 2009년 당시, SEWB의 회원 및 후원자 수는 50 명 정도 에 불과하였으나, 이로부터 약 9년 뒤 2019년 기준 단체 소 식지를 받는 회원 및 후원자는 4,824여명으로 크게 증가하 였다.

$\mathrm{SEWB}$ 의 활동가들을 중심으로 학술 및 교육 활동, 현지 봉사활동이 수행되었으며, 현재까지 38개 단체와 $\mathrm{MOU}$ 를 체결하였다. 특히, 'SEWB-(재)자연드림씨앗재단(전 (재)한 국사회적경제씨앗재단 (iCOOP(i-ideal-innocence-innovation Cooperative) 생활협동조합, iCOOP KOREA, 이하 iCOOP 생협)) 개도국 식수 공공성 사업'과 '글로벌 물 적정기술 센 터 (Innovative Water Center, iWc) 구축 사업'을 중심으로 다수의 사업 및 과제가 수행되었으며, 최근 SEWB는 캄보 디아 라이프 대학교와 (사)함께한대, (주)요크, (주필로스, 적 정기술 대학생 봉사단(8명), 봇뱅 마을 주민협의체와 협력 하고 (주)삼성전자와 사랑의 열매 사회복지공동모금회로부 터 후원을 받아 '캄보디아 고립 마을 주민의 삶의 질 개선 과 소득 증대를 위한 적정기술 마을 조성 사업'을 수행하고 있다.

이 연구에서는 SEWB에서 지난 11년간 수행한 각종 사업 을 요약 정리하고 그 의미를 공유하고자 한다. 특히, 캄보 디아, 미얀마 등 다수의 지역을 중심으로 기술 보급 및 교 육을 수행하였던 기존 사업과 및 현재 추진 중인 캄보디아 봇뱅 마을을 대상으로 하는 적정기술 마을 조성 사업 사례 로 크게 구분하여 보고하고자 한다. 


\section{연구방법}

\section{1. 기존 사업 정리}

SEWB의 사업 활동(2012-2019) 자료를 확보하기 위하여 SEWB 연례보고서(SEWB, 2014, SEWB, 2015, SEWB, 2017, SEWB, 2018, SEWB, 2019)와 SEWB 홈페이지(http:/ /sewb.org) 내 사업소개 중 물/환경 페이지에 개시된 자료의 제목과 기재된 내용을 바탕으로 추출하였다.

\section{1 물/환경 분야}

1.1.1 SEWB 적정기술 수처리 장치

$\mathrm{SEWB}$ 에서 개발한 3 종류의 적정기술 수처리 장치의 구 성과 사진 및 기타 자료는 식수 공급용 수처리 장치로, 정 수처리 패키지(Simple water package (Sim. WP)) 와 태양에 너지 기반 정수처리 패키지(Solar water package (Sol. WP), 생활용수 공급용 시스템(Community development water system (CDWS))으로 구분하여 정리하였다.

1.1.2 개도국 내 SEWB 식수 공급용 수처리 장치의 적용 사례

앞서 언급된 3종류의 수처리 장치 중 식수 공급용 2종에 대하여 연도 및 급수 인구의 범주(0-50, 51-100, 101-250, 251-500, 501-1000,1001-1500 명) 별로 2012-2019년까지 4
개 개도국(캄보디아, 미얀마, 필리핀, 가나)을 대상으로 수 처리 장치의 현장 적용 사례를 정리하였다. 개도국 별 수처 리 장치 설치 대상지마다 적용된 수처리 장치 설치 대수와 급수 인구가 명시된 자료만을 활용하였다.

1.1.3 캄보디아 지역 별 식수 공급용 수처리 장치의 설치 대수 분포

앞 장의 자료를 바탕으로 SEWB 수처리 장치의 설치 대 수가 가장 많은 캄보디아에 대하여 캄보디아 지역 별(주 단 위) 설치 대수를 정리하였다. 수처리 장치가 설치된 주가 불 명확한 경우, 인터넷 검색을 통하여 주소지를 추가 확보하 거나, 인터넷 검색도 불가능 한 경우에는 자료 정리 시 제 외하였다.

\section{2 학술 및 교육 분야}

학술 및 교육에 대한 자료는 SEWB의 연례보고서 내 학 술 및 교육을 목차로 구분하여 정리해 놓은 것을 기반으로 작성하였다. 학술 활동은 과제(Project), 출판(Publication), 모임 및 이벤트(Meetings and events)로 분류하였다.

$\mathrm{SEWB}$ 의 사업활동 (글로벌 물 적정기술 거점센터 $(\mathrm{iWc}) 4$ 차년도 사업, 2차년도 후속 사업)은 과제로 구분하고, $\mathrm{SEWB}$ 에서 출판한 책 권수 당 1 건으로 계산하여 출판으로 구분하였다. 워크샵과 세미나는 모임 및 이벤트로 분류하

Table 1. Detailed information of the developed water systems in SEWB

\begin{tabular}{|c|c|c|c|}
\hline Title & Speciation & Picture & Etc. \\
\hline $\begin{array}{l}\text { Simple water } \\
\text { package } \\
\text { (Sim. WP) }\end{array}$ & $\begin{array}{c}\text { Pre-filter, } \\
\text { activated carbon filter, } \\
\text { ultrafiltration }(\mathrm{UF}) \text { module } \\
(>60 \mathrm{~L} / \mathrm{hr}), \\
\text { reverse osmosis }(\mathrm{RO}) \\
\text { module }(>15 \mathrm{~L} / \mathrm{hr})\end{array}$ & & $\begin{array}{l}\text {-Weight: } 5 \mathrm{~kg} \\
\text { - Rated input voltage: } \\
110 \mathrm{~V} / 220 \mathrm{~V}\end{array}$ \\
\hline $\begin{array}{l}\text { Solar water } \\
\text { package } \\
(\text { Sol. WP) }\end{array}$ & $\begin{array}{c}\text { Simple water package, } \\
\text { Photovoltaic panel, } \\
\text { Battery } \times 2\end{array}$ & & $\begin{array}{l}\text { - Daily maximum } \\
\text { operational time using } \\
\text { solar energy } \\
\text { : up to } 4 \sim 6 \mathrm{hr} / \text { day }\end{array}$ \\
\hline $\begin{array}{c}\text { Community } \\
\text { development } \\
\text { water system } \\
\text { (CDWS) }\end{array}$ & $\begin{array}{l}\text { 1) Groundwater (direct } \\
\text { use) } \\
\text { 2) Rainwater harvesting, } \\
\text { sand filter } \\
\text { 3) River water, sand filter, } \\
\text { sediment filter }\end{array}$ & & $\begin{array}{l}\text { - Capacity for domestic } \\
\text { water (not for drinking } \\
\text { water source) } \\
: 5,000 \sim 10,000 \mathrm{~L}\end{array}$ \\
\hline
\end{tabular}


여 각각의 개수를 합하여 정리하였다. 교육은 봉사 활동과 강의 그리고 경진대회, 3 개의 항목으로 분류하여 각각의 개 수를 합하여 정리하였다. 이 중에서 강의는 교육 캠프와 초 중고 학생을 대상으로 한 적정기술 강의를 합하여 계산하 였다.

\section{2. 봇뱅 마을 사례 정리}

$\mathrm{SEWB}$ 에서 주관하여 진행하고 있는 '캄보디아 고립 마을 주민의 삶의 질 개선과 소득 증대를 위한 적정기술 마을 조 성 사업(SEWB Sustainable village development project)'에 대한 정보를 확보하였다(Kim, 2020). 이를 기반으로 20192020년도까지의 캄보디아 시하누크빌 주 봇뱅 마을에 구축 및 설치한 시설과 장치의 용도와 용량을 정리하고, 적정 기 술의 적용 전/후 차이를 나타내었다.

\section{결과 및 토의}

\section{SEWB 물/환경 사업 정리 (2012-2019)}

\section{1 개발된 적정기술 수처리 장치}

$\mathrm{SEWB}$ 는 식수 공급용 수처리 장치 2개(정수처리 패키지, 태양에너지 기반 정수처리 패키지) 와 생활용수 공급용 시 스템 1개(CDWS)를 개발하였다(Table 1).

정수처리 패키지는 전처리 필터(Pre-filter), 활성탄 필터 (Activated carbon filter), UF 분리막 모듈(UF module), 역삼 투 모듈(RO module)의 4단계를 거쳐 식수를 생산하는 장치 이다. 정수처리 패키지의 UF 분리막 모듈에서 $60 \mathrm{~L} / \mathrm{hr}$ 의 만 큼의 전처리 수가 생산된 뒤 다시 역삼투 모듈을 통해 15 $\mathrm{L} / \mathrm{hr}$ 만큼의 처리된 식수가 생산된다. 장치의 정격전압은 $110 \mathrm{~V} / 220 \mathrm{~V}$ 이며 외부 전력이 필요하여 따라서 전기 공급이 열악한 지역에서는 사용하기 어렵다.

태양에너지 기반 정수처리 패키지는 기존의 정수처리 패 키지에 태양광 패널을 장착하여 전력공급이 원활하지 못한 지역에서도 식수를 생산할 수 있는 장치이다. 여기에는 2 개 의 배터리가 장착되어 있다.

생활용수 공급용 시스템은 지표수(강물), 지하수, 빗물을 이용하여 직접 식수로 활용은 불가능한 생활용수를 공급 하는 시설로서, 유입수 조건에 따라 다른 공정들이 적용되 었다.

\section{2 개발된 적정기술 수처리 장치의 현장 적용 사례}

1.2.1 연도/급수 인구/지역별 현장 적용 사례 2012년부터 현재까지 4개 국가(캄보디아, 미얀마, 필리핀, 가나)에 총 225 개의 식수 생산용 수처리 장치가 현장에 설
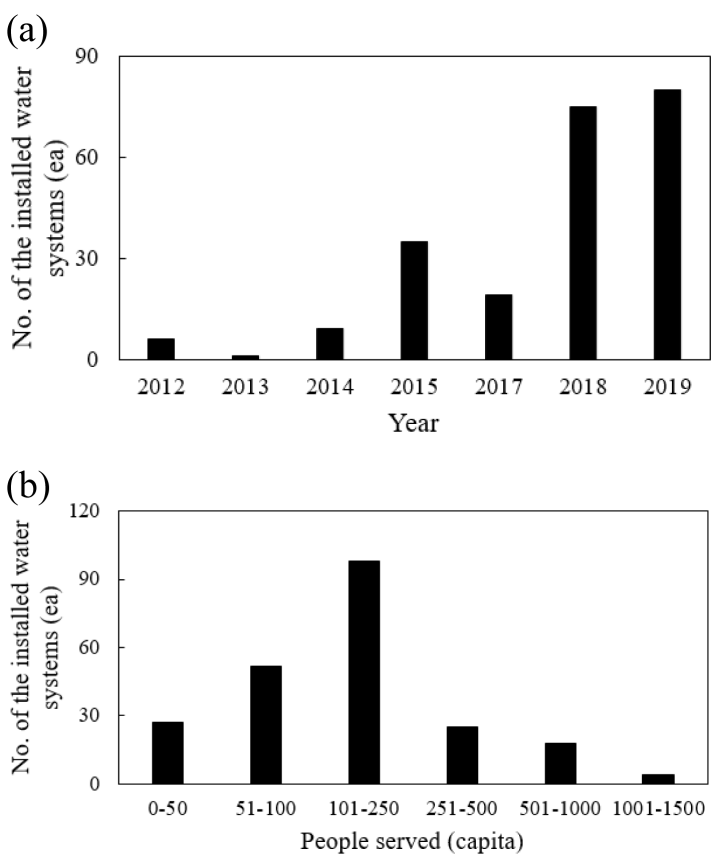

Figure 1. The number of the installed water systems in developing countries during 2012-2019 (a: according to their installed year and $\mathrm{b}$ : according to the people served)

치되었으며 총 급수 인구는 22,335명이었다.

Figure 1(a)에 연도 별 수처리 장치 설치 대수를 나타내었 다. SEWB에서는 2013년을 제외하고 약 20-50대의 수처리 장치를 개도국에 매년 보급하였다. 2015년 이후 식수 공급 용 수처리 장치의 설치 대수가 급증하였는데, 이는 iCOOP 생협의 지원이 증가되었기 때문이다.

또한, 급수 인구 별로 식수 공급용 수처리 장치 설치 대 수를 Figure 1(b)에 도시하였다. 250명 이하 급수 인구 규모 의 지역에 주로 공급하였으며, 500 명 이상의 급수 인구 대 상지역에 설치된 경우는 상대적으로 적었다.

장치 별 매년 설치된 수를 아래 Table 2에 정리하였다. 특 히 정수처리 패키지가 211개로 가장 많이 설치되었고, 태양 에너지 기반 정수처리 패키지가 14 대, 생활용수 공급용 시 스템이 9대 설치되었다. 정수처리 패키지의 설치 대수가 2015년 이후 급증하였으며, 이는 적어도 전기가 보급된 지 역에 많은 식수 공급 사업이 진행된 것으로 판단된다. 이는 2017년부터 태양에너지 기반 정수처리 패키지가 설치되지 않은 경향과 일치하는 것으로 판단된다. 생활용수 공급용 시스템의 경우는 현장 설치 자료가 적어 경향을 파악하기 가 어려웠다.

식수 공급용 수처리 장치를 보급한 국가별 급수 인구를 Figure 2에 도시하였다. SEWB에서는 캄보디아 > 미얀마 > 필리핀 > 가나 순으로 많은 주민에게 물 공급을 하였으며, 
Table 2. Detailed information of the installed water systems in developing countries

\begin{tabular}{ccccccccc}
\hline & 2012 & 2013 & 2014 & 2015 & 2017 & 2018 & 2019 & Total \\
\hline Simple water package (Sim. WP) & 2 & 1 & 4 & 30 & 19 & 75 & 80 & 211 \\
$\begin{array}{c}\text { Solar water package (Sol. WP) } \\
\text { Community development }\end{array}$ & 4 & - & 5 & 5 & - & - & - & 14 \\
$\quad$ water system (CDWS) & 2 & 1 & 3 & - & 3 & unknown & unknown & 9 \\
& & & & & & & 234 \\
\hline
\end{tabular}

가나의 경우 1 개 가정에 1 건 공급 되었기 때문에 Figure 2 에 나타내지 않았다.

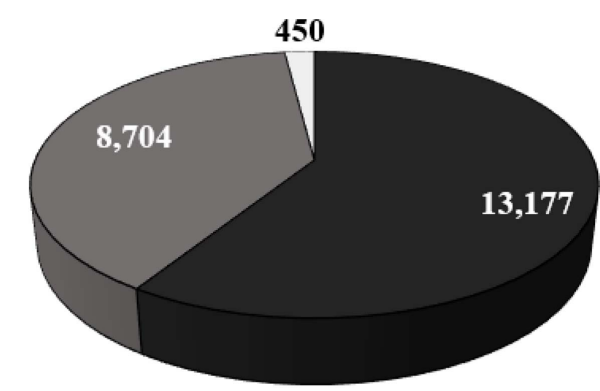

Cambodia 口Myanmar 口Philippines

Figure 2. The number of people served in developing countries during 2012-2019

캄보디아의 경우, 각 수처리 장치에 대하여 주 별 현장 설 치 위치 정보를 확보할 수 있어, 다음 장에 그림으로 정리
하였다. 미얀마의 경우, 현장 설치 위치를 확보하지 못하여 따로 정리하지 못하였다.

\subsection{2 캄보디아 주 별 현장 적용 사례 정리}

Figure 3에 나타나 있듯이, SEWB에서는 캄보디아 수도 (프놈펜, Phnom Penh) 및 24개 주 중 수도와 13개 주에 총 53 건의 식수 공급용 수처리 장치를 현장 적용 하였다. 수 도인 프놈펜 지역에 가장 많은 식수 시설(26개)이 적용되었 으며, 다음으로 시엡 립(Siem Reap) 주에 21대, 캄퐁 스프 (Kampong Speu)와 캄퐁 참(Kampong Cham) 주에 각각 11 대와 10 대가 설치되었다. 설치대수와 급수인수의 비율은 전 지역적으로 큰 차이를 보이지 않았다.

\section{SEWB 학술 및 교육 사업}

아래 Table 3에 SEWB에서 수행하였던 학술 및 교육 사 업을 정리하여 나타내었다. SEWB의 활동가들은 20102020 년도까지 총 29 건의 학술 활동과 총 57 건의 교육 활동

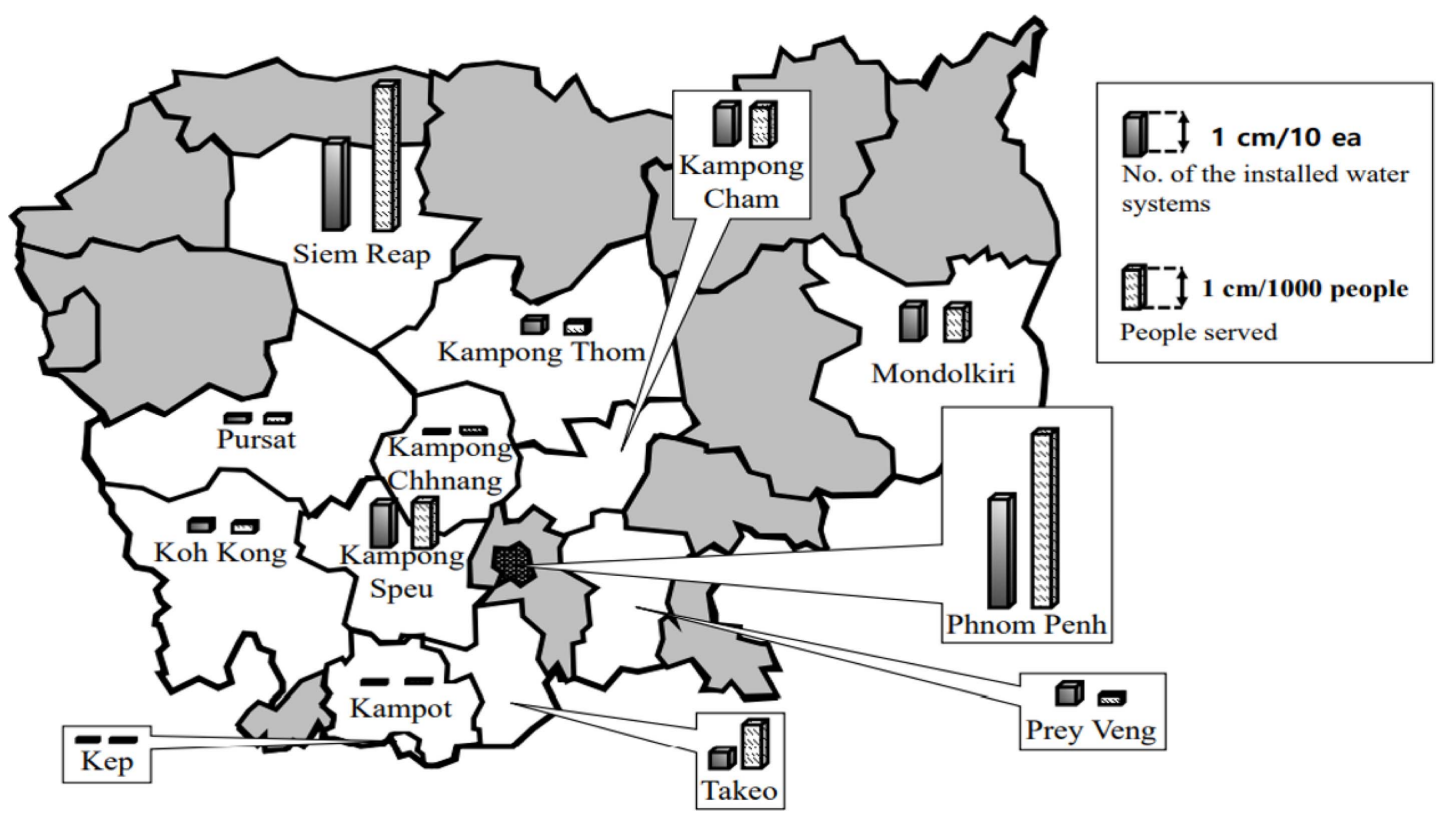

Figure 3. Spatial distributions of the applied water systems in Cambodia 
을 수행하였다. SEWB 국내 전문가들은 캄보디아 적정기술 거점센터(iWc) 설립 과제를 바탕으로 캄보디아 현지 네트 워크를 구축하고, 현지 물 관련 기술 수요를 파악함으로써 다수의 $\mathrm{ODA}$ 사업으로 파급될 수 있는 거점을 제공한 바 있다.

Table 3. Summary of R\&D activities and educations in SEWB (2010-2020)

\begin{tabular}{|l|c|}
\hline & No. \\
\hline Academic works & 29 \\
\hline - Project & 2 \\
\hline - Publication & 3 \\
\hline - Meetings and events & 24 \\
\hline $\begin{array}{l}\text { International conference on } \\
\text { appropriate technology }\end{array}$ & 11 \\
\hline Other conferences & 3 \\
\hline Workshops and seminars & 10 \\
\hline & No. \\
\hline Educations & 57 \\
\hline - Lectures & 40 \\
\hline - Volunteer works & 11 \\
\hline - Competitions & 6 \\
\hline
\end{tabular}

적정기술국제학회(International conference on appropriate technology, ICAT)를 매년 1 회 주관 및 공동주관으로 개최 하고 있으며, 다수의 세미나 및 워크샵을 수행하고 있다. 이 를 통하여 적정기술 분야의 전문가들이 모여 SEWB의 활 동 분야를 기존의 물, 교육 등의 분야에서 에너지, 농축산, 식품영양, 주거건축, 보건의료 및 국제협력 분야로 확장할 수 있었다. 또한, 적정기술 관련 교재 및 서적을 출판하여, $\mathrm{SEWB}$ 의 활동을 소개하고 이를 교육에도 활용하고 있다.

$\mathrm{SEWB}$ 에서는 적정 기술 교육을 위해 국내 매년 3-4회 적 정기술관련 강의를 수행하고 있다. 2010-2020년도 까지 초 중고 학생 대상 24회, 대학생 대상 13 회, 일반인 대상 2 회, 및 전문가 대상 1 회의 강의가 수행되었다. 특히, 아시아에너지 환경지속 가능발전연구소(AIEES, Asian Institute for Energy, Environment and Sustainability) 강의(9회), 대학생을 위한 적정기술 Challenge (3회) 및 적정기술 창의설계 워크숍(3 회)과 같은 프로그램의 형태로 다수의 대학생을 대상으로 하는 강의들이 진행되었다. 이것은 적정기술 관련 강의의 주요 대상이 대학생 또는 초중고 학생이었음을 의미한다. $\mathrm{SEWB}$ 의 활동가 분들이 주로 대학교수나 중고등학교 교사 와 같이 국내 교육 전문가이었기 때문이다.

또한, $\mathrm{SEWB}$ 의 지원으로 6 개 국가(캄보디아, 미얀마, 필 리핀, 베트남, 네팔, 가나)에 11 번의 적정기술 해외봉사활동
이 추진되었으며, 봉사활동 과정에서 현지 주민 대상 교육 도 함께 이루어졌다. 이 중에서 빈도가 높았던 봉사활동은 서울대학교 제 7 기와 10 기 스누봉사단 활동이었다. 베트남 현지에 물 관련 과학 교육 캠프를 2회 수행하였다. 그리고 2017 하계 캄보디아 해외 봉사단 활동과 2019 적정기술 봉 사로 캄보디아의 프놈펜 수도와 시하누크빌 주에 태양광을 활용해 가정용 전기를 생산할 수 있는 적정 기술의 설치와 운영 방법에 대한 교육을 2회 수행하였다.

SEWB는 2010-2020년도 까지 국내 대학 및 대학원생을 대상으로 '소외된 $90 \%$ 를 위한 창의 설계 경진대회'를 매년 공동주관으로 개최하여 IT 적정 기술과 위생, 안전, 농업 분 야의 작품 및 아이디어 설계와 시상을 통해 수상작품 및 아 이디어를 현장에 적용 하는 사업을 진행하고 있다.

\section{SEWB 개도국 현지 통합 솔루션 제공 사업: 봇뱅 마을 사례}

2019-2020년도에 SEWB의 주관 하에 '캄보디아 고립 마 을 주민의 삶의 질 개선과 소득 증대를 위한 적정기술 마 을 조성 사업'의 일환으로 다른 협력 기관 및 단체와 함께 캄보디아 시하누크빌 주 외곽에 있는 봇뱅 마을에 적정기 술 마을 조성 사업을 수행하였다. SEWB 와 협력 기관 및 단체들은 사회적인프라가 없는 봇뱅 마을의 열악한 환경을 개선하기 위해 1) 교량 교체, 2) 전력 생산 및 공급 시설 설 치, 3) 식수 생산을 위한 담수화 시설 설치, 4) 양계장 구축 사업을 진행하였다(Table 4).

\section{1 교량 교체 사업}

SEWB에서 추진하고 있는 '캄보디아 고립 마을 주민의 삶의 질 개선과 소득 증대를 위한 적정기술 마을 조성 사 업’이 진행되기 이전인 2018년도까지 봇뱅 마을과 시하누 크빌 주를 연결하는 목교가 있었는데 낡고 부서진 상태로 차량 통행이 어려웠고 대부분의 주민들은 뗏목을 타고 강 을 가로질러 이동해야 했다. 2019년도에 교량 교체 사업을 통해 기존의 통행 하중이 $1 \mathrm{t}$ 미만이었던 목교를 $1 \mathrm{t}$ 이상의 통행 하중을 갖는 목교로 교체하였다. $1 \mathrm{t}$ 이상의 차량 통행 이 가능해지며 이 때문에 목교 진입로에 훍이 손실되는 일 이 발생하게 되었다. 이를 개선하고자 2020년도 목교 진입 로 밑면에 자갈을 깔고 그 위를 콘크리트 작업을 수행하였 다. 또한, 과적 덤프트럭의 이용을 제한하기 위해 높이제한 철제물을 교량 진입로에 설치하였다.

\section{2 전력 생산 및 공급 시설 설치}

봇뱅 마을에 위치한 봇뱅 학교(Bot Veng friend primary school) 은 초등학교와 중학교가 같이 있고 약 150 여명의 학 생 이용하는 시설이다. 2018년도 당시 이 곳은 전기 시설이 
Table 4. Detailed information of the solutions for Bot Veng village, Cambodia

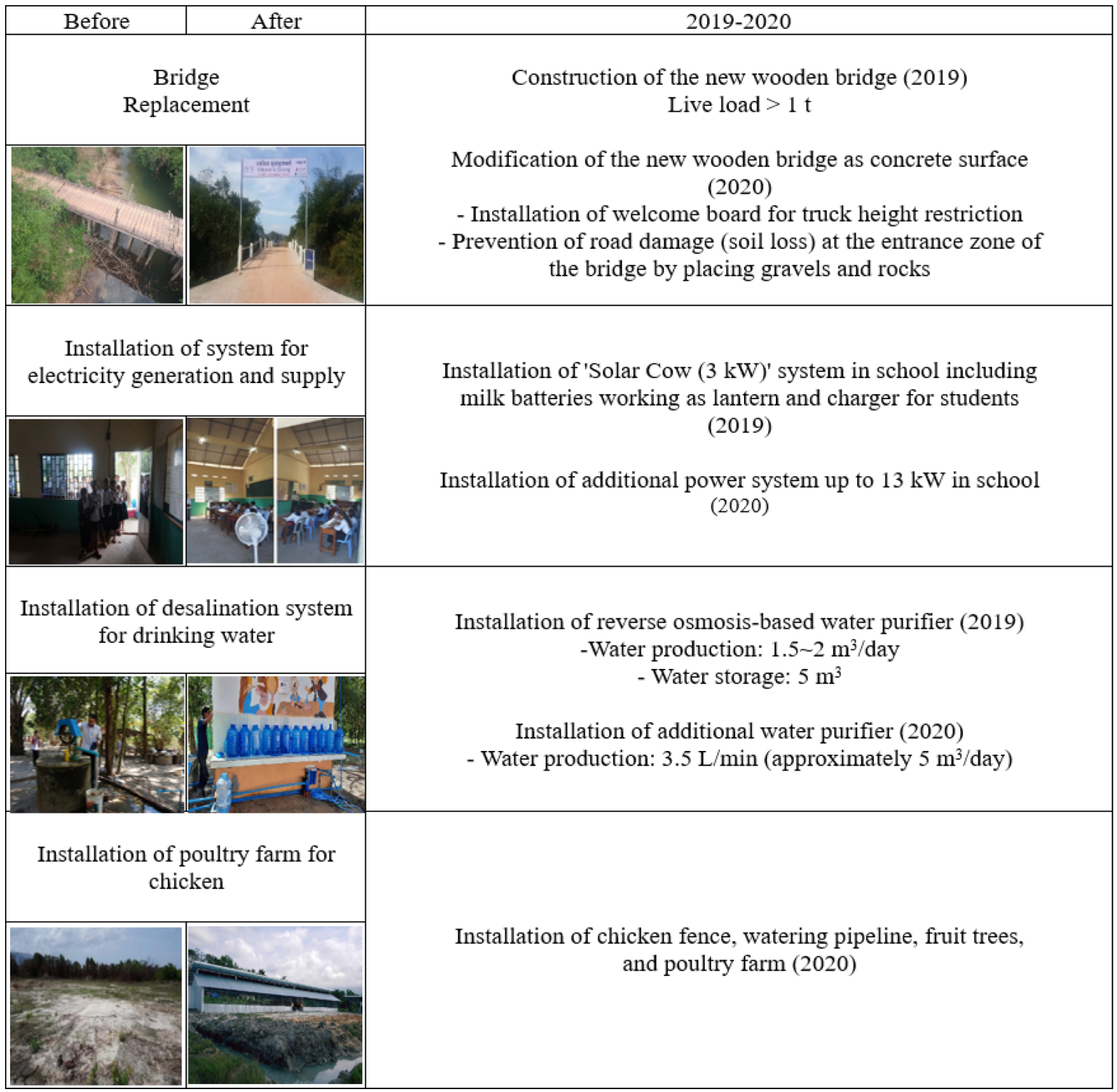

없는 열악한 교육 환경이었다.

$\mathrm{SEWB}$ 와 (주)요크, 적정기술봉사단 학생들은 2019년 태 양광 패널을 이용하여 $3 \mathrm{~kW}$ 의 전력을 생산할 수 있는 '솔 라 카우(Solar Cow)' 시스템을 교실 지붕 위에 설치하였다. 솔라 카우 시스템을 이용하여, 수업 시간 동안 '밀크 배 터리'에 전기를 충전하고 하교 시 학생들이 집으로 가져가 각 가정에서 휴대용 램프 및 전력원으로 활용할 수 있다. 2020 년에는 총 $13 \mathrm{~kW}$ 의 전기를 생산 및 공급할 수 있는 시 설로 확충하였다.

\section{3 식수 생산을 위한 담수화 시설 설치}

2018년도 당시 봇뱅 마을의 가용 수자원은 주변 강물과
지하수 그리고 빗물이었으며, 바닷가와 인접해 있기 때문 에 강물과 지하수 내 염분 농도가 높은 특성을 갖고 있었 다. 봇뱅 마을 주민들은 특별한 정수 설비 시설 없이 지하 수(봇뱅 학교 내 우물)를 직접 식수로 활용해 왔다. 봇뱅 학 교 내 우물물을 분석한 결과, 캄보디아의 14 개의 수질검사 항목(pH, turbidity, TDS, $\mathrm{F}^{-}, \mathrm{Cl}^{-}, \mathrm{NO}_{3}{ }^{2-}, \mathrm{SO}_{4}{ }^{2-}, \mathrm{NH}_{4}{ }^{+}, \mathrm{As}, \mathrm{Mn}$, $\mathrm{Fe}$, total hardness, Coliform bacteria, E. coli) 중 아래 Table 5 의 1 번부터 6 번까지의 6 개 항목 $\left(\mathrm{Cl}^{-}(<250 \mathrm{mg} / \mathrm{L}): 1,300\right.$ $\mathrm{mg} / \mathrm{L}$, TDS (<800 mg/L): 2,500 mg/L, Fe $(<0.3 \mathrm{mg} / \mathrm{L}): 0.7$ $\mathrm{mg} / \mathrm{L}$, total hardness $(<300 \mathrm{mg} / \mathrm{L}): 720 \mathrm{mg} / \mathrm{L}$, turbidity $(<5$ NTU): 6.5 NTU, Coliform Bacteria (0 cfu/100 ml): $400 \mathrm{cfu} /$ $100 \mathrm{~mL})$ 이 먹는 물 수질 기준을 초과하였다. 
Table 5. Water quality of feed water for RO system in Bot Veng, Cambodia

\begin{tabular}{|c|c|c|c|c|}
\hline No. & Parameter & $\begin{array}{c}\text { Standard of } \\
\text { drinking water }\end{array}$ & Unit & Testing result \\
\hline 1 & $\mathrm{Cl}^{-}$ & $<250$ & $\mathrm{mg} / \mathrm{L}$ & 1,300 \\
\hline 2 & $\mathrm{Fe}$ & $<0.3$ & $\mathrm{mg} / \mathrm{L}$ & 0.7 \\
\hline 3 & Turbidity & $<5$ & NTU & 6.5 \\
\hline 4 & TDS & $<800$ & $\mathrm{mg} / \mathrm{L}$ & 2,500 \\
\hline 5 & Total hardness & $<300$ & $\mathrm{mg} / \mathrm{L}$ & 720 \\
\hline 6 & Coliform bacteria & 0 & $\mathrm{cfu} / 100 \mathrm{~mL}$ & 400 \\
\hline 7 & $\mathrm{pH}$ & $6.5-8.5$ & & 6.8 \\
\hline 8 & $\mathrm{~F}^{-}$ & $<1.5$ & $\mathrm{mg} / \mathrm{L}$ & 0.4 \\
\hline 9 & $\mathrm{NO}_{3}{ }^{2-}$ & $<50$ & $\mathrm{mg} / \mathrm{L}$ & 0.4 \\
\hline 10 & $\mathrm{SO}_{4}^{2-}$ & $<250$ & $\mathrm{mg} / \mathrm{L}$ & 0.45 \\
\hline 11 & $\mathrm{NH}_{4}^{+}$ & $<1.5$ & $\mathrm{mg} / \mathrm{L}$ & 0.05 \\
\hline 12 & As & $<50$ & $\mu \mathrm{g} / \mathrm{L}$ & 0 \\
\hline 13 & $\mathrm{Mn}$ & $<0.1$ & $\mathrm{mg} / \mathrm{L}$ & 0.01 \\
\hline 14 & E. coli & 0 & $\mathrm{cfu} / 100 \mathrm{~mL}$ & 0 \\
\hline
\end{tabular}

이에 따라, 2019년 SEWB와 (주)필로스 및 적정기술봉사 단 학생들은 지하수를 유입 원수로 이용하여 약 $1.5 \sim 2 \mathrm{~m}^{3} /$ day의 식수를 생산할 수 있는 역삼투 공정 기반의 식수 생 산 장치를 설치하였다(2019.07.27-2019.08.03). 2020년에는 라이프 대학교 (Life University)의 관계자 및 이제열 선교사 의 도움으로 현지 주민들과 함께 총 $3.5 \mathrm{~L} / \mathrm{min}$ (약 $5 \mathrm{~m}^{3} /$ day) 의 식수를 생산할 수 있는 설비로 증설하였다. 담수화 공정 기반의 식수 설비 설치 이후, 모든 항목에서 먹는 물 기준 을 만족하는 수준으로 판정되었다(Table 6).

Table 6. Water quality of treated water for RO system in Bot Veng, Cambodia

\begin{tabular}{|c|c|c|c|c|}
\hline No. & Parameter & $\begin{array}{c}\text { Standard of } \\
\text { drinking water }\end{array}$ & Unit & Testing resul \\
\hline 1 & $\mathrm{Cl}^{-}$ & $<250$ & $\mathrm{mg} / \mathrm{L}$ & 55 \\
\hline 2 & $\mathrm{Fe}$ & $<0.3$ & $\mathrm{mg} / \mathrm{L}$ & 0.02 \\
\hline 3 & Turbidity & $<5$ & NTU & 0.5 \\
\hline 4 & TDS & $<800$ & $\mathrm{mg} / \mathrm{L}$ & 100 \\
\hline 5 & Total hardness & $<300$ & $\mathrm{mg} / \mathrm{L}$ & 30 \\
\hline 6 & Coliform bacteria & 0 & $\mathrm{cfu} / 100 \mathrm{~mL}$ & 0 \\
\hline 7 & $\mathrm{pH}$ & $6.5-8.5$ & & 6.2 \\
\hline 8 & $\mathrm{~F}^{-}$ & $<1.5$ & $\mathrm{mg} / \mathrm{L}$ & 0.1 \\
\hline 9 & $\mathrm{NO}_{3}{ }^{2-}$ & $<50$ & $\mathrm{mg} / \mathrm{L}$ & 1.4 \\
\hline 10 & $\mathrm{SO}_{4}{ }^{2-}$ & $<250$ & $\mathrm{mg} / \mathrm{L}$ & 0.65 \\
\hline 11 & $\mathrm{NH}_{4}^{+}$ & $<1.5$ & $\mathrm{mg} / \mathrm{L}$ & 0.01 \\
\hline 12 & As & $<50$ & $\mu \mathrm{g} / \mathrm{L}$ & 0 \\
\hline 13 & $\mathrm{Mn}$ & $<0.1$ & $\mathrm{mg} / \mathrm{L}$ & 0.02 \\
\hline 14 & E. coli & 0 & $\mathrm{cfu} / 100 \mathrm{~mL}$ & 0 \\
\hline
\end{tabular}

\section{4 양계장(Bot Veng Dream Farm) 구축 사업}

봇뱅 마을 주민들은 전기와 수도 공급이 원활하지 못한 열악한 환경과 고립된 특성으로 인하여, 주민의 $60 \%$ 는 오 일 야자수를 재배하고, $20 \%$ 는 낚시 기반의 어업활동을 하 였으며, 나머지 $20 \%$ 는 농사를 지어 하루 가구 소득이 5 달
러 이하였다.

2020년도 SEWB의 지원으로 이제열 선교사 및 라이프대 학교 관계자, 봇뱅 마을 주민협의체가 협력하여, 봇뱅 학교 의 뒷 편에 양계장 부지를 확보하였다. 양계장 부지 선정 이 후 마을 주민들이 정지 작업 및 울타리 설치 작업을 수행 하였다. 또한, 농업 용수 공급을 위한 급수관 공사를 수행 한 이후, 총 1,000 마리 수용 가능한 양계장 시설을 구축하 였다.

\section{5 기타 사항}

COVID-19로 인하여 현지 방문이 어려웠던 2020년의 경 우, SEWB의 현지 활동에 큰 어려움이 예상되었다. 하지만, 국내 전문가들의 도움을 받아, 현지 선교사, 현지 대학 관 계자, 봇뱅 마을 주민 협의체의 도움으로 2020년에도 계획 된 현지 사업을 추진할 수 있었다.

아울러, 2018년도 당시 봇뱅 마을 주민들은 사회적 인프 라 부족으로 인해 출퇴근이나 병원 등 시내로의 이동이 제 한적이었다. 이를 해소하고자 SEWB는 (사)함께한대 의료 팀과 협력하여 2019년도 건강진단 및 처방을 위해 예진, 소 아 진료, 일반 진료, 약국 운영, 치과 진료, 검체 채취, 집단 검사 등의 봉사활동을 수행하여 현지 주민들의 건강 복지 향상에 기여하고자 하였다.

\section{결론}

$\mathrm{SEWB}$ 는 캄보디아를 중심으로 한 주변 동남아시아 지역 국가들의 주민 복지 또는 생활 수준 향상에 기여하였다.

한정된 자원으로 개도국을 지원하는 경우, 여러 지역에 검증된 기술을 보급하는 경우와, 한 지역에 통합 솔루션을 제공하는 경우 모두 의미가 있다고 판단된다. SEWB는 11 년의 경험을 바탕으로 다양한 형태의 개도국 지원 포트폴 리오를 확보할 수 있었다.

현재 수행되었던 방식을 따른다면 앞으로 타 지역에서도 적정 기술의 보급 및 현지 주민 생활 향상이 가능할 것으 로 기대된다.

$\mathrm{SEWB}$ 가 수행하였던 글로벌 물 적정기술 거점센터 사업 (과기부, 2013 2019)과 같은 거점센터사업이 일몰사업화 되고 있다. 국가 $\mathrm{ODA}$ 예산이 지속 증가될 것으로 예측되 는 현재 시점에서 현지에 기술을 보급하여 주민 생활 향상 에 대한 효과가 큰 현지거점형 사업에 대한 재추진이 필요 할 것으로 판단된다.

앞으로 SEWB 활동이 지속되는 경우, 결과적으로는 개도 국과 선진국의 사회 인프라 격차를 줄여 나갈 수 있고 세 계 물 부족 문제 해결에 기여할 것으로 판단된다. 


\section{References}

Engineers without borders (EWB) Australia. (2021). https:// ewb.org.au/ (accessed April, 2021).

Engineers without borders (EWB) Canada. (2021). https:// www.ewb.ca/en/ (accessed April, 2021).

Engineers without borders (EWB) UK. (2021). https://www.ewbuk.org/ (accessed April, 2021).

Engineers without borders (EWB) USA. (2021). https:// www.ewb-usa.org/ (accessed April, 2021).

Kim, Y. (2020). The story of an isolated rural village in Cambodia (BOTVENG STORY), Global Korea Convention 2020, National Research Council for Economics, Humanities and Social Scientists, The K-Hotel, Seoul.

SEWB (Scientists and Engineers Without Borders). (2014).
Annual report.

SEWB (Scientists and Engineers Without Borders). (2015). Annual report.

SEWB (Scientists and Engineers Without Borders). (2017). Annual report.

SEWB (Scientists and Engineers Without Borders). (2018). Annual report.

SEWB (Scientists and Engineers Without Borders). (2019). Annual report.

SEWB (Scientists and Engineers Without Borders). (2021). http:/ /www.sewb.org/ (accessed April, 2021).

The World Bank. (2020). Poverty and shared prosperity 2020. P. 28-46.

UNFCCC. (2021). TT:CLEAR, https://unfccc.int/ttclear/tna (accessed April, 20). 